\title{
OPTIMIZATION OF MILLING FARM RESIDUES USING A LOCAL HAMMER MILL
}

\author{
ABD EL MOTTALEB A.F.*, \\ EL DAHSHAN W.A.** and BEJO L.***
}

\section{ABSTRACT}

Field crop residues are considered to be one of the most critical problems facing the Egyptian farmers. The first step towards solving this problem is to cut, crush and mill these lignocellulosic materials in order to be used as raw materials in several industries.

For optimizing the milling parameters, the performance of a local hammer mill machine was experimentally investigated during crushing some different types of farm residues (cotton stalks, maize stalks and rice straw), as a function of change in hammer drum speed, concave hole diameter and the residues moisture content. The machine performance was evaluated in terms of machine productivity, particle size distribution, and energy requirements.

The experimental results revealed that the performance of the hammer mill was in the optimum region under the following conditions:

Hammer drum speed of $44.2 \mathrm{~m} / \mathrm{s}$, concave hole diameter of $2 \mathrm{~mm}$ and residues moisture content of maize stalks $4.1 \%$, rice straw $3.4 \%$ and cotton stalks $7.4 \%$.

Key words:

Hammer mill, milling parameters, farm residues, optimization.

\footnotetext{
* ASSOC. PROF., AGR. RES. CENTRE, AGR. ENG. RES. INST., CAIRO, EGYPT.

** ENG.AL OBOUR HIGH INST. OF ENG. AND TEC., CAIRO, EGYPT

*** ASSOC.PROF., INST.OF WOOD AND PAPER TEC., FAC. OF WOOD SC., UNI. OF WEST HUNGARY, SOPRON, HUNGARY
} 


\section{INTRODUCTION}

$\mathrm{F}$ Vield crop residues are considered to be one of the most critical problems facing the Egyptian farmers. In Egypt, about 30 million tons of agricultural residues are generated each year (Ministry of Agriculture, Egypt 2007).

The utilization of field crop residues instead of burning them became an important point of research because these residues are considered to be a heavy burden and a serious environmental problem at the national level.

The first step towards solving this problem is to cut, crush and mill these residues using hammer mill machines to minimize their volume in order to be used as lignocellulosic raw materials in several industries.

Abdel-Mottaleb (1993) reported that the field crop residues can be reutilized instead of getting rid of it by burning which causes a great damage of air pollution to the environment.

The crushed output of these residues was used in the manufacture of untraditional animal fodder and composite boards.

Hashish et al. (1994) studied some factors affecting the performance of chopping, crushing and grinding equipment for field raw materials, they concluded that the optimum speed was found as $9.4 \mathrm{~m} / \mathrm{s}$ for the three tested raw materials and the highest production rate and efficiency were obtained at low levels of moisture content of raw materials.

Egela et al.(2003) studied the effect of some operational parameters on the fineness of the ground corn and also on the power consumption. The screen opening size was the most significant factor affecting the mill performance and the ground corn fineness. The screen opening size of 14 $\mathrm{mm}$, number of hammers of 45 and the speed of $28.6 \mathrm{~m} / \mathrm{s}$ resulted in medium ground corn fineness. The screen opening size of $6 \mathrm{~mm}, 60$ hammers and $36.7 \mathrm{~m} / \mathrm{s}$ were used, the hammer mill feed opening and rotor shaft speed were the most significant factors affecting energy requirements.

Imbabi (2003) tested the performance of a cutting machine for crop residues in the cutting process of corn stalks. The obtained results showed that the use of a serrated edge knife significantly decreased the cutting energy requirements by 8-15\% and increased the cut length of less than 
$5 \mathrm{~cm}$ length by about $90 \%$, and it also increased the service life by a factor of $1.18-2.25$, as compared to the smooth edge knives.

Yousf (2005) reported that the power requirements of the grinding operation increased with increasing feed rates, while it decreased with increasing screen opening size. The best results of power consumption were obtained at $29.5 \mathrm{~m} / \mathrm{s}$ hammer speed, $550 \mathrm{~kg} / \mathrm{h}$ feeding rate and screen opening sizes of 6-9 mm for soybean and maize crops respectively. Abdel Mottaleb and Obaia (2006) tested and evaluated a hammer mill machine for milling date palm leaves. The machine was used at different milling speeds, different leaf moisture contents and different concave hole diameters to assess the machine productivity, efficiency, energy requirements and fineness degree. Results showed that the optimum machine performance was obtained at $4.8 \%$ leaves moisture content, 1200 rpm drum speed and $22 \mathrm{~mm}$ concave hole diameter.

Hegazy (2006) developed and evaluated a grain crusher of local make. The results revealed that optimum operating conditions were obtained at $44.21 \mathrm{~m} / \mathrm{s}$ hammer speed, 22.5 degrees of hammer edge angle and 7.94 $\mathrm{mm}$ size. At these levels maximum crusher productivity of 0.228 ton and lowest power requirement of $3.521 \mathrm{~kW}$ and energy consumption 2.447 $\mathrm{kW} . \mathrm{h} /$ ton were obtained.

Morad et al. (2007) investigated the performance of a crop residues chopping machine during cutting some field residues such as rice straw, corn stalks and sugarcane in terms of the percentage of cutting lengths, energy and cost requirements. Optimum performance was obtained at chopper rotating speed of $51.31 \mathrm{~m} / \mathrm{s}$, material feed rates of $0.45 \mathrm{ton} / \mathrm{h}$ for sugarcane, at residues moisture content of $5.5 \%$ for rice straw, $8.7 \%$ for corn stalks and $11 \%$ for sugarcane residues.

The main objective of this research is to test and improve the performance of a laboratory small hammer mill equipment during cutting and crushing some crop residues such as rice straw, cotton and maize stalks.

Also to optimize some operating parameters affecting the performance of the used hammer mill machine such as the drum speed, moisture content of crop residues and concave hole diameter. 


\section{MATERIALS AND METHODS}

Experiments were carried out by using a laboratory local hammer mill machine in the workshop of the Agricultural Engineering Research Institute, Dokki, Egypt.

\section{Materials:}

\section{The used crops residues:}

In this study, crushing and milling operations were carried out on maize stalks, rice straw and cotton stalks which are three of the main strategic crops in Egypt.

The specifications of the used crop residues were as follows:

The average mass values of maize stalks, rice straw and cotton stalks were 408, 48.5 and $191 \mathrm{~g}$ respectively, meanwhile the average length values were $218.5,96$ and $122.7 \mathrm{~cm}$ for the same residues in sequence . The average diameter values of maize stalks, rice straw and cotton stalks were $21.5,4$ and $8.2 \mathrm{~mm}$ respectively, meanwhile the range of moisture content values were $(4.1-20.9 \%),(3.4-10.6 \%)$ and $(7.4-20.9 \%)$ for the same residues in sequence.

\section{The hammer mill machine:}

A local hammer mill machine was used for crushing and milling the agricultural field residues (Fig 1).

The technical specifications of the machine are shown in Table (1)

Table (1): The technical specifications of the hammer mill machine.

\begin{tabular}{|l|l|}
\hline Item & Specification \\
\hline - Make & Locally \\
\hline - Type & Laboratory hammer mill \\
\hline - Hammers & \\
Number & 10 hammer knives \\
Mass (gm) & 1875 \\
Length $(\mathrm{cm}) \quad 12.8$ \\
Width $\quad(\mathrm{cm})$ & 5 \\
Thickness (mm) & 6 \\
\hline - Diameters of the concave holes $(\mathrm{mm})$ & $2,4,7$ \\
\hline - Clearance between knife and concave $(\mathrm{mm})$ & 4 \\
\hline - Power source & Single phase electric \\
& motor, 1.84 kW, 220 V, \\
\hline
\end{tabular}


The power was transmitted from the source to the driving shaft by a v-belt and pulleys. Feeding was performed manually.

\section{Methods:}

Experiments were carried out to optimize some operating parameters that affect the performance of the hammer mill machine. The main parameters and experimental conditions were selected according to the relevant studies on the crushing and milling of the solid raw materials, as follows:

Four drum speeds of $20.1,28.1,36.2$ and $44.2 \mathrm{~m} / \mathrm{s}$, three concave hole diameters of 2,4 and $7 \mathrm{~mm}$, and four moisture contents of the crop residues (4.1, 9.4,15.2 and 20.9\%) for maize stalks, (3.4, 6.7,8.2 and $10.6 \%)$ for rice straw and $(7.4,10.1,14.7$ and $20.9 \%)$ for cotton stalks.

The four values of moisture content for each crop residue were taken on the following basis :

The first value was taken at the end of the harvest season (after complete dryness), the second and third values at the middle of the harvest season and the fourth value after a month from the beginning of the harvest season.

Ten hammer knives used in this machine, 5 of them were with an edge angle of 22.5 degrees on the longitudinal axis of the hammers, while the other 5 hammers were made with a flat edge angle of 90 degrees on the longitudinal axis of the hammers. All free ends of the hammers were made with a graduated spike surface to increase the sheer force on the raw materials as shown in Fig. (2).

The evaluation of the hammer mill performance was carried out taking into consideration the following indicators:

\section{Machine productivity:}

The running time of the experiment was measured by a stop watch. The machine productivity was calculated by dividing the crushed mass with the required time of crushing $(\mathrm{kg} / \mathrm{h})$.

\section{Particle size distribution of the output product:}

Seven standard sieves from the central laboratory of the Agricultural Engineering Research Institute, Dokki, Egypt, were used (2,3.35,9.53, $12.7,19.05,25.4$ and $>25.4 \mathrm{~mm})$ to determine the particle size distribution of the output product(ASAE 2001). The total weight of 
samples and the mass of each product categories were weighed using a precise digital scale with an accuracy of $0.01 \mathrm{~g}$.

The percent distribution of each fraction was determined by dividing the fraction's mass with the total mass of the output product.

\section{The energy requirements:}

- Total consumed power $(\mathrm{kW})$ under working load was determined by using a wattmeter (700 - k type).

- The power was estimated from the measured electric current and voltage values. The actual power of the machine was estimated according to (Kurt, 1979) as follows from equation [1].

$\mathrm{P}=\sqrt{3}, \mathrm{I} \cdot \mathrm{V} . \quad \xi \cdot \cos \theta \quad / 1000 \mathrm{~kW}$

\section{Where}

I : electric current in Amperes, V: electrical voltage (220V),

$\xi$ : mechanical efficiency (assumed to be $95 \%$ ), and $\cos \theta$ : power factor (was taken as $85 \%$ )

Thus, the consumed energy can be calculated by dividing the required power with the machine productivity $(\mathrm{kW} . \mathrm{h} / \mathrm{kg}$ )

\section{The raw-material moisture content:}

The moisture content of raw materials was determined by drying them in an electric oven adjusted at $105^{\circ} \mathrm{C}$ for 24 hours. The net moisture content was calculated using the AOAC(1996) methods. 


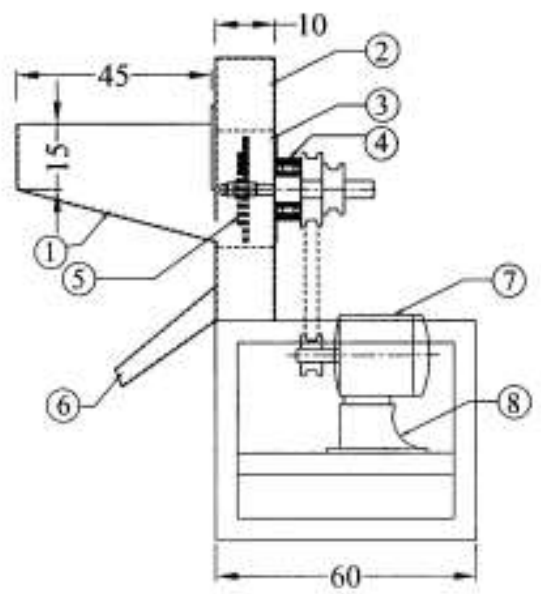

ELEVATION

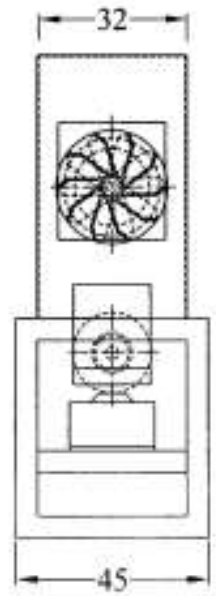

SIDE VIEW
1- Feeding opener.

2-Chassis.

3- Knives champer.

4- Bearing.

5- Hammer mill knives.

6- Out-put opener.

7- E. M.

8- Steel stand.

Fig. (1): Local hammer mill machin.
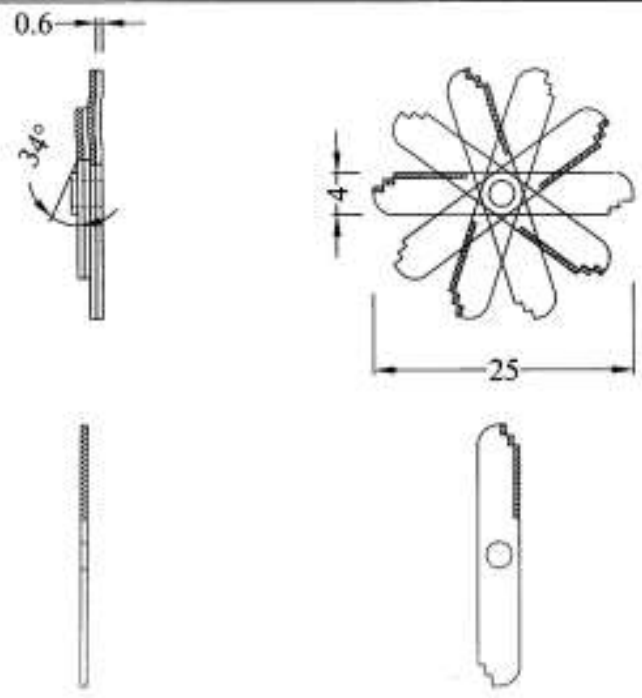

Dim. in $\mathrm{cm}$

S.V.

ELEVATION

Fig. (2): Hammermill knives after modification. 


\section{RESULTS AND DISCUSSION}

The discussion will cover the obtained results under the following heads:

\section{Particle size distribution:}

\subsection{Effect of drum speed on the particle size distribution at different concave hole diameters:}

The obtained results of particle size distribution values are tabulated in Table(2).

Concerning maize stalks, the results obtained show that increasing the drum speed from $20.1 \mathrm{~m} / \mathrm{s}$ to $44.2 \mathrm{~m} / \mathrm{s}$ increased the particle size distribution of $<2 \mathrm{~mm}$ from 35.1 to $53.1 \%$, from 20 to $24.5 \%$, and from 19 to $23 \%$ at concave hole diameters of 2,4 , and $7 \mathrm{~mm}$ respectively and moisture content of $4.1 \%$.

Relating to rice straw, the results obtained show that increasing the drum speed from $20.1 \mathrm{~m} / \mathrm{s}$ to $44.2 \mathrm{~m} / \mathrm{s}$ increased the particle size distribution of $<2 \mathrm{~mm}$ from 43.4 to $65.5 \%$, while decreased from 54.2 to $8.8 \%$, and from 33.1 to $28.6 \%$ at concave hole diameters of $2,4,7 \mathrm{~mm}$ respectively and moisture content of $3.4 \%$.

As to cotton stalks, the results obtained show that increasing drum speed from $20.1 \mathrm{~m} / \mathrm{s}$ to $44.2 \mathrm{~m} / \mathrm{s}$ increased the particle size distribution of $<2$ $\mathrm{mm}$ from 45.6 to $53.5 \%$ and from 21 to $30 \%$, while decreased from 26.7 to $8.5 \%$ at concave hole diameters of 2,4 , and $7 \mathrm{~mm}$ respectively and moisture content of $7.4 \%$.

\subsection{Effect of the residues moisture content on the particle size distribution at different concave hole diameters:}

The obtained results of particle size distribution values are tabulated in Table(3).

Concerning maize stalks, the obtained results show that increasing the moisture content from 4.1 to $20.9 \%$ decreased the particle size distribution of $<2 \mathrm{~mm}$ from 53.1 to $48 \%$, from 24.5 to $18.4 \%$, and from 23 to $18.4 \%$ at concave hole diameters of 2,4 , and $7 \mathrm{~mm}$ respectively and constant drum speed of $44.2 \mathrm{~m} / \mathrm{s}$.

Relating to rice straw, the obtained results show that increasing the moisture content from 3.4 to $10.6 \%$ decreased the particle size distribution of $<2 \mathrm{~mm}$ from 65.5 to $51 \%$, from 8.8 to $4.96 \%$, and from 
28.6 to $23.1 \%$ at concave hole diameters of 2,4 , and $7 \mathrm{~mm}$ respectively and constant drum speed of $44.2 \mathrm{~m} / \mathrm{s}$.

As to cotton stalks, the obtained results show that increasing the moisture content from $7.4 \%$ to $20.9 \%$ decreased the particle size distribution of < $2 \mathrm{~mm}$ from 53.5 to $43.4 \%$, from 30 to $25 \%$, while increased from 8.5 to $32.4 \%$ at concave hole diameters of 2,4 , and $7 \mathrm{~mm}$ respectively and constant drum speed of $(44.2 \mathrm{~m} / \mathrm{s})$. 
Table (2): Effect of the drum speed on the particle size distribution of maize stalks, rice straw and cotton stalks at various concave hole

diameters (at residues moisture content of $4.1 \%, 3.4 \%$ and $7.4 \%$ respectively)

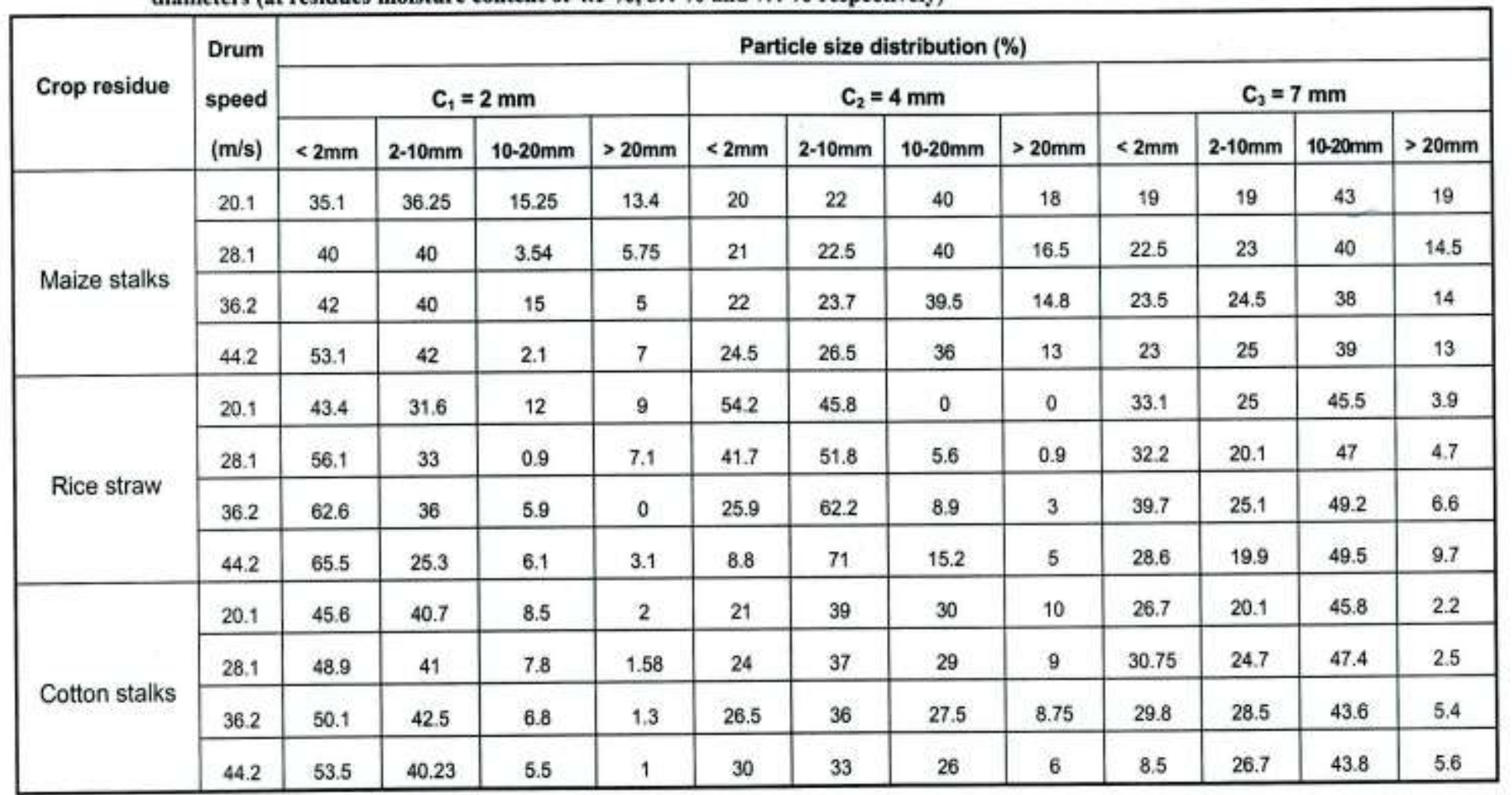


Table (3): Effect of the moisture content on the particle size distribution of maize stalks, rice straw and cotton stalks at various concave hole diameters (at constant drum speed of $44.2 \mathrm{~m} / \mathrm{s}$ )

\begin{tabular}{|c|c|c|c|c|c|c|c|c|c|c|c|c|c|}
\hline \multirow{3}{*}{ Crop residue } & \multirow{3}{*}{$\begin{array}{c}\text { Moisture } \\
\text { content } \\
(\%) \\
\end{array}$} & \multicolumn{12}{|c|}{ Particle size distribution } \\
\hline & & \multicolumn{4}{|c|}{$C_{1}=2 \mathrm{~mm}$} & \multicolumn{4}{|c|}{$\mathrm{C}_{2}=4 \mathrm{~mm}$} & \multicolumn{4}{|c|}{$C_{3}=7 \mathrm{~mm}$} \\
\hline & & $<2 \mathrm{~mm}$ & 2-10mm & $10-20 \mathrm{~mm}$ & $>20 \mathrm{~mm}$ & $<2 \mathrm{~mm}$ & 2-10 mm & $10-20 \mathrm{~mm}$ & $>20 \mathrm{~mm}$ & $<2 \mathrm{~mm}$ & $2-10 \mathrm{~mm}$ & $10-20 \mathrm{~mm}$ & $>20 \mathrm{~mm}$ \\
\hline \multirow{4}{*}{ Maize stalks } & 4.1 & 53.1 & 42 & 2.1 & 7 & 24.5 & 26.5 & 36 & 13 & 23 & 25 & 39 & 13 \\
\hline & 9.4 & 49.09 & 31.96 & 6.12 & 12.83 & 22.3 & 25 & 42.5 & 20.8 & 22.3 & 25 & 41,5 & 11.2 \\
\hline & 15.2 & 48.5 & 32.1 & 8.1 & 10.1 & 40.4 & 23 & 45.2 & 20.5 & 20.4 & 23 & 41.8 & 14.9 \\
\hline & 20.9 & 48 & 33 & 11 & 8 & 18.4 & 21 & 48.2 & 28.3 & 18.4 & 21 & 42.1 & 18.5 \\
\hline \multirow{4}{*}{ Rice straw } & 3.4 & 65.5 & 25.3 & 6.1 & 3.1 & 8.8 & 71 & 15.2 & 5 & 28.6 & 19.9 & 49.5 & 9.7 \\
\hline & 6.7 & 60.7 & 20.9 & 10.5 & 7.9 & 5.83 & 70 & 19 & 5.2 & 25 & 22.6 & 52.4 & 0 \\
\hline & 8.2 & 56.6 & 17.9 & 14.7 & 10.8 & 5.1 & 69.9 & 18.8 & 4.9 & 24,1 & 21.6 & 54.1 & 0 \\
\hline & 10.6 & 51 & 15.8 & 19.1 & 14.1 & 4.96 & 61.7 & 20.1 & 6.24 & 23.1 & 20.9 & 56 & 0 \\
\hline \multirow{4}{*}{ Cotton stalks } & 7.4 & 53.5 & 40.23 & 5.5 & 1 & 30 & 33 & 26 & 6 & 8.5 & 26.7 & 43.8 & 5.6 \\
\hline & 10.1 & 48.5 & 44.8 & 8.7 & 5.4 & 30 & 37 & 20 & 8 & 26.2 & 25.9 & 49.3 & 8 \\
\hline & 14.7 & 46 & 42.1 & 12.9 & 3.1 & 32.6 & 38.2 & 22.2 & 8.9 & 29.3 & 21 & 51.8 & 10.4 \\
\hline & 20.9 & 43.4 & 39.5 & 17.1 & 0 & 25 & 40 & 25 & 10 & 32.4 & 15.1 & 55.7 & 12.8 \\
\hline
\end{tabular}




\section{Machine productivity :}

\subsection{Effect of drum speed on machine productivity at different concave hole diameters:}

Fig. (3) shows the effect of drum speed on machine productivity at different concave hole diameters during milling maize stalks $(4.1 \%$, $\mathrm{MC})$, rice straw (3.4\% $\mathrm{MC})$ and cotton stalks ( $7.4 \% \mathrm{MC})$.

Concerning maize stalks, the obtained data show that increasing drum speed from $20.1 \mathrm{~m} / \mathrm{s}$ to $44.2 \mathrm{~m} / \mathrm{s}$ increased the machine productivity from 25.5 to 42.9 ,from 38.1 to 60.4 , and from 60.9 to $89.7 \mathrm{~kg} / \mathrm{h}$ with concave hole diameters of 2,4 and $7 \mathrm{~mm}$ respectively and constant moisture content of $4.1 \%$.

Relating to rice straw, data show that increasing drum speed from 20.1 $\mathrm{m} / \mathrm{s}$ to $44.2 \mathrm{~m} / \mathrm{s}$ increased machine productivity from 15.86 to 20.56 , from 23.8 to 31.4 and from 30.94 to $47.1 \mathrm{~kg} / \mathrm{h}$ with concave hole diameters of 2,4 and $7 \mathrm{~mm}$ respectively and constant moisture content of $3.4 \%$.

As to cotton stalks, the results obtained show that increasing drum speed from $20.1 \mathrm{~m} / \mathrm{s}$ to $44.2 \mathrm{~m} / \mathrm{s}$ increased machine productivity from 22.5 to 40 , from 30 to 50 and from 35 to $57 \mathrm{~kg} / \mathrm{h}$ with concave hole diameters of 2,4 and $7 \mathrm{~mm}$ respectively and constant moisture content of $7.4 \%$.

\subsection{Effect of the residues moisture content on the machine productivity at different concave hole diameters:-}

Fig. (4) shows the effect of moisture content on machine productivity at different concave hole diameters during milling maize stalks, rice straw and cotton stalks with a constant drum speed of $44.2 \mathrm{~m} / \mathrm{s}$.

Concerning maize stalks, the obtained data show that increasing moisture content from 4.1 to $20.9 \%$ decreased machine productivity from 42.9 to $25.4 \mathrm{~kg} / \mathrm{h}$, from 60.4 to $39.7 \mathrm{~kg} / \mathrm{h}$ and from 89.7 to $45.6 \mathrm{~kg} / \mathrm{h}$ with concave hole diameters of 2,4 and $7 \mathrm{~mm}$ respectively and constant drum speed of $44.2 \mathrm{~m} / \mathrm{s}$.

Relating to rice straw, data show that increasing moisture content from 3.4 to $10.6 \%$ decreased machine productivity from 20.56 to $9.2 \mathrm{~kg} / \mathrm{h}$, from 31.4 to $15.78 \mathrm{~kg} / \mathrm{h}$ and from 47.1 to $23.67 \mathrm{~kg} / \mathrm{h}$ with concave hole 
diameters of 2,4 and $7 \mathrm{~mm}$ respectively and constant drum speed of 44.2 $\mathrm{m} / \mathrm{s}$.

As to cotton stalks, the results obtained show that increasing moisture content from 7.4 to $20.9 \%$ decreased machine productivity from 40 to $32.2 \mathrm{~kg} / \mathrm{h}$, from 50 to $40 \mathrm{~kg} / \mathrm{h}$, and from 57 to $52 \mathrm{~kg} / \mathrm{h}$ with concave hole diameters of 2,4 and $7 \mathrm{~mm}$ respectively and constant drum speed of 44.2 $\mathrm{m} / \mathrm{s}$. 

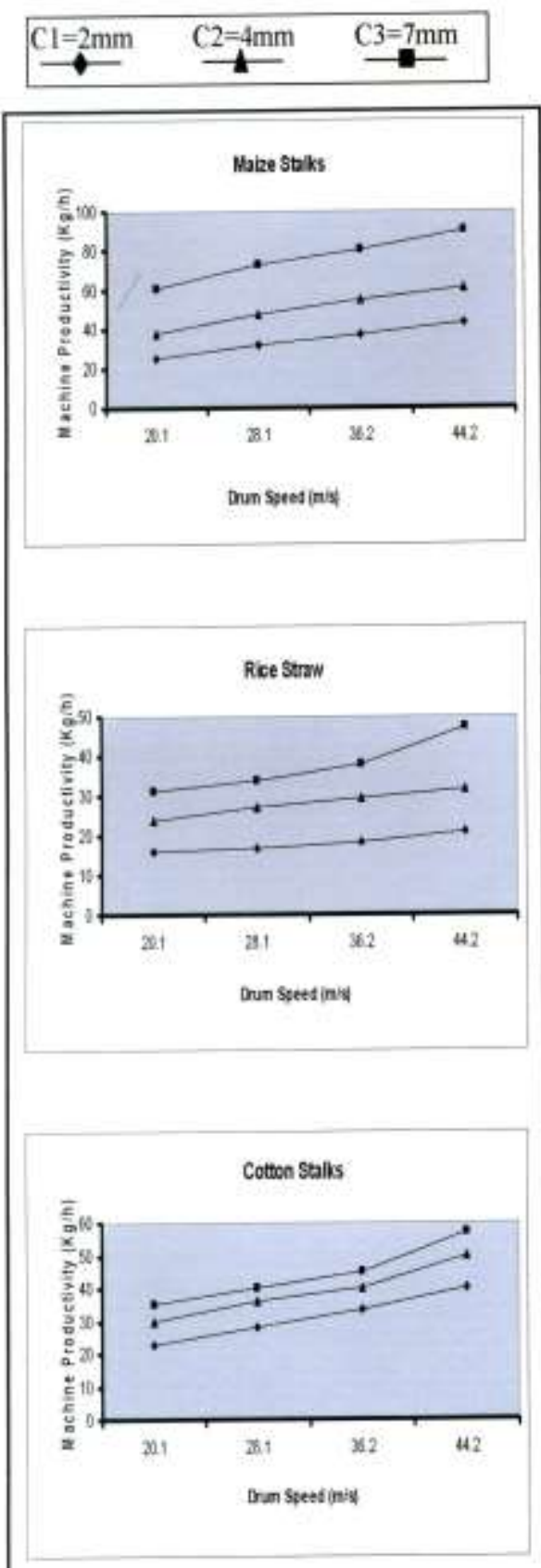

Fig. (3) : Effect of drum speed on the machine productivity at different concave hole diameters during milling maize stalks, rice straw, and cotton stalks with $4.1,3.4$, and $7.4 \% \mathrm{MC}$ respectively.
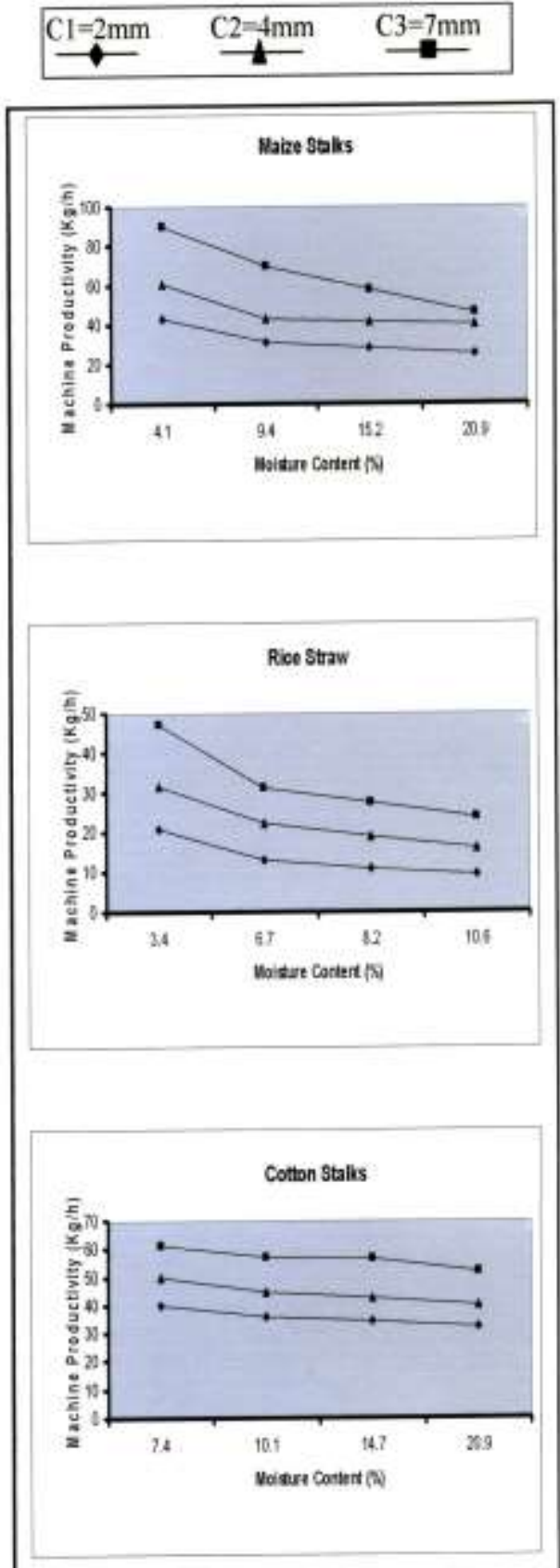

Fig.(4) : Effect of residues moisture content on the machine productivity at different concave hole diameters and constant drum speed of $44.2 \mathrm{~m} / \mathrm{s}$ 


\section{Energy requirements:}

\subsection{Effect of drum speed on energy requirements at different concave hole diameters:}

Fig. (5) shows the effect of drum speed on energy requirements at different concave hole diameters during milling maize stalks $4.1 \% \mathrm{MC}$, rice straw 3.4\% MC, and cotton stalks 7.4\% MC.

Concerning maize stalks, the obtained data show that increasing drum speed from $20.1 \mathrm{~m} / \mathrm{s}$ to $44.2 \mathrm{~m} / \mathrm{s}$ increased energy requirements from 34.47 to 40.94 , from 23.89 to 30 , and from 15.39 to $21.12 \mathrm{~kW} . \mathrm{h} . / \mathrm{kg}$ at concave hole diameters 2,4 and $7 \mathrm{~mm}$ respectively and $4.1 \% \mathrm{MC}$.

Relating to rice straw, data show that increasing drum speed from 20.1 $\mathrm{m} / \mathrm{s}$ to $44.2 \mathrm{~m} / \mathrm{s}$ increased energy requirements from 70.43 to 102.8 , from 48.24 to 71.2 , and from 38.14 to $51.39 \mathrm{~kW} . \mathrm{h} / \mathrm{kg}$ at concave hole diameters 2,4 and $7 \mathrm{~mm}$ respectively and $3.4 \% \mathrm{MC}$.

As to cotton stalks, the results obtained show that increasing drum speed from $20.1 \mathrm{~m} / \mathrm{s}$ to $44.2 \mathrm{~m} / \mathrm{s}$ increased energy requirements from 53.63 to 65.45 , from 36.56 to 44.81 and from 35.87 to $44.8 \mathrm{~kW}$. h/kg at concave hole diameters 2,4 and $7 \mathrm{~mm}$ respectively and $7.4 \% \mathrm{MC}$.

\subsection{Effect of moisture content on energy requirements at different concave hole diameters:}

Fig. (6) shows the effect of moisture content on energy requirements at different concave hole diameters during milling maize stalks, rice straw and cotton stalks at constant drum speed of $44.2 \mathrm{~m} / \mathrm{s}$.

Concerning maize stalks, the obtained data show that increasing moisture content from 4.1 to $20.9 \%$ increased the energy requirements from 40.94 to 150 , from 30 to 100.9 , and from 21.12 to $66.78 \mathrm{~kW} . \mathrm{h} / \mathrm{kg}$ with concave hole diameters 2,4 and $7 \mathrm{~mm}$ respectively and constant drum speed of $44.2 \mathrm{~m} / \mathrm{s}$.

Relating to rice straw, data show that increasing moisture content from 3.4 to $10.6 \%$ increased energy requirements from 102.8 to 253.7 , from 71.2 to 157.16 , and from 50.28 to $117.45 \mathrm{kWh} / \mathrm{kg}$, with concave hole diameters 2,4 and $7 \mathrm{~mm}$ respectively and constant drum speed of $44.2 \mathrm{~m} / \mathrm{s}$.

As to cotton stalks, the results obtained show that increasing moisture content from 7.4 to $20.9 \%$ increased energy requirements from 53.13 to 81.16, from 30.86 to 44.6 , and from 43.47 to $68.85 \mathrm{~kW} . \mathrm{h} / \mathrm{kg}$ with concave hole diameters 2,4 and $7 \mathrm{~mm}$ respectively and constant drum speed of $44.2 \mathrm{~m} / \mathrm{s}$ 

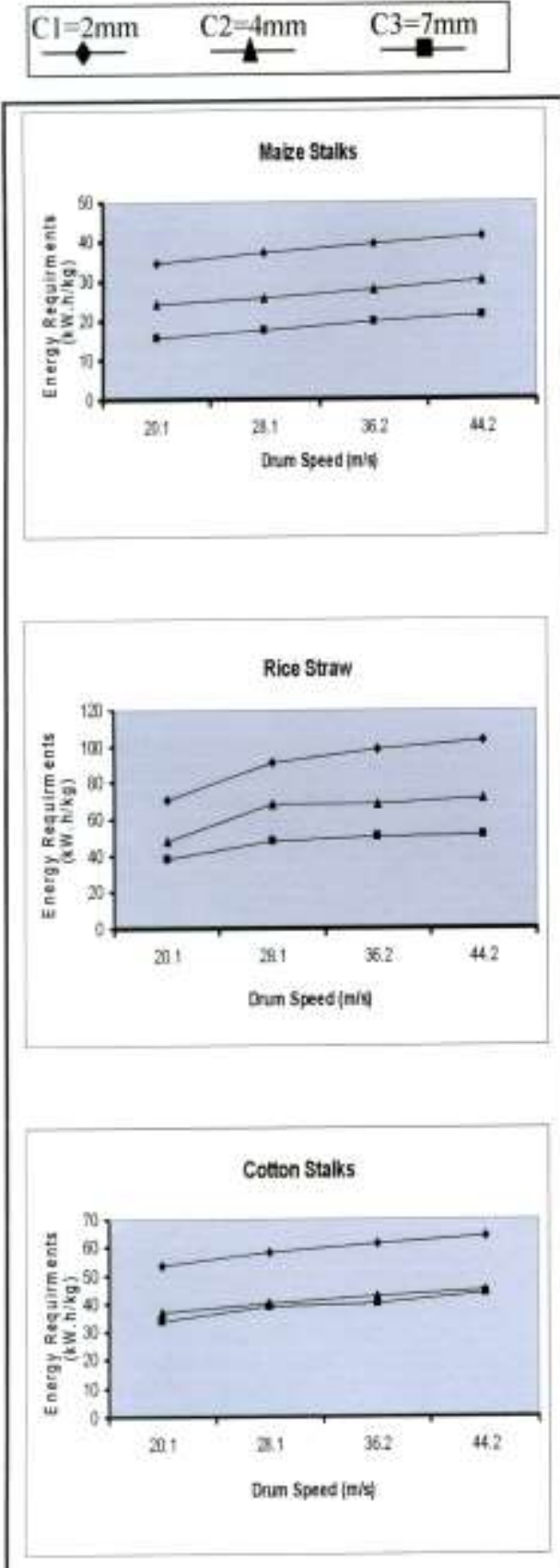

Fig.(5): Effect of drum speed on Energy requirements at different concave hole diameters during milling maize stalks $(4.1 \% \% \mathrm{MC})$, rice straw $(3.4 \% \mathrm{MC})$, and cotton stalks $(7.4 \% \mathrm{MC})$
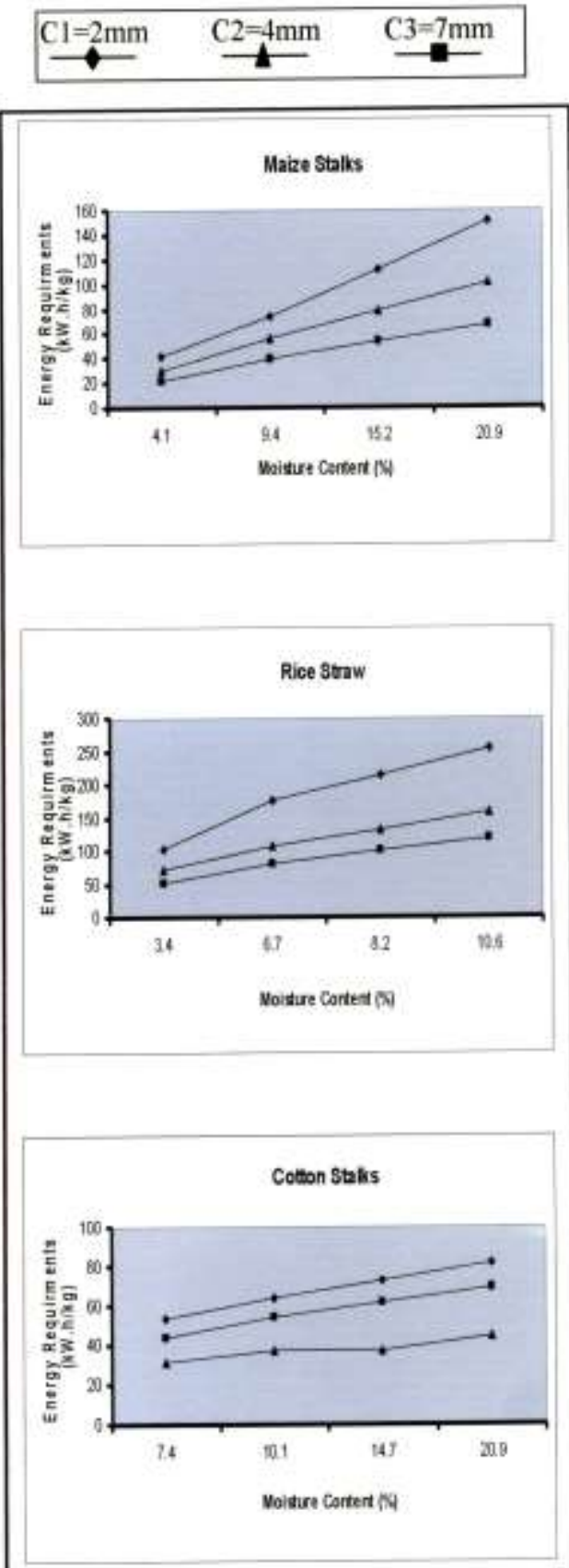

Fig. (6): Effect of residues moisture content on energy requirements at constant drum speed of $44.2 \mathrm{~m} / \mathrm{s}$. 


\section{CONCLUSION}

The conclusions of the present study can be summarized as follows:

Performance of the hammer mill was optimum under the following conditions:

1. Hammer drum speed $44.2 \mathrm{~m} / \mathrm{s}$

2. Concave hole diameter $2 \mathrm{~mm}$

3. Residues moisture content of maize stalks $4.1 \%$, rice straw $3.4 \%$ and cotton stalks $7.4 \%$.

\section{REFERENCES}

Abd El-Mottaleb, A.F. (1993): A study of crushing machines for the agricultural field raw material for industrialization and factors affecting the softness degree and pink boll worms control. M.Sc. Fac. of Agric. Agric. Eng. Dept. Zagazig U.

Abd El-Mottaleb, A. F.; and A.R. Obaia (2006) : Study on manufacture of animal fooder from date palm leaves. J. Agric. Sci. Mansoura U. 31 (7): 163-175.

Agricultural Statistics (2007): Economic Affairs Sector. Ministry of Agr. and Land Rec. Cairo, Egypt.

AOAC (1996): Official methods of analysis, $20^{\text {th }}$ Ed., Assoc.of Official Analyt. Chem. Wash. D.C.

ASAE (2001) : Methods of determining and expressing fineness of feed materials by sieving. American Society of Agricultural Engineering standards, $45^{\text {th }}$ Ed. S 319.3 , St. Joseph, Mich.

Egela, M.I.; Y.F. Sharobeen ; and M.E. Badawy (2003) : Modification of some operational parameters for a local manufactured hammer mill. The 11th Ann. Conference of the Misr Soc. of Ag. Eng. , 15-16 Oct., 830-840.

Egyptian Standard Specification of Wood (1993,2006): ES 906, UDC 674, part 1,2 and UDC 3578, part 2,4. Egyptian Organization for Standardization and Quality control. Cairo, Egypt. 
Hashish, A.E.; M.A. Hassan and A.F. Abd El-Mottaleb (1994): Some factors affecting performance of chopping, crushing and grinding equipment for field raw-materials. J. Chopping grinding equipment. Misr J. Ag. Eng. , 11 (3) : 669-682.

Hegazy K.E. (2006): Development and evaluation a locally made grain crusher to suit production of livestock feeds from date pits. J. Agric. Sci. Mansoura U., 31.

Imbabi, A.T., (2003): Improving a crop-residues cutting machine for environment preservation. Misr. J. Agr. Eng., 20 (3): 783-805.

Kurt, G. (1979): Engineering formulas . $3^{\text {rd }}$. Ed. Mc Graw - Hill book Co.

Morad, M.M. M.,A. Aranout, O.A. Omar and H.I. Ahmed (2007): Effect of mechanical chopping and adding different farm residues on soil physical properties and wheat yield. Zagazig J. Agric. Res., 34 (4): 781-804.

Yousef, I.S. (2005): A study on performance improvement of the local manufactured hammer mill used in poullity forms. J. Agric., Sci. Mansoura Univ., 2) (11): 6827-6840.

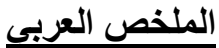

تحديد العوامل المثلي لطحن المخلفات الحقلية بإستخدام الة طدن محلية الصنع

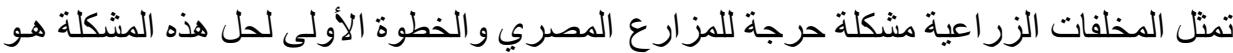

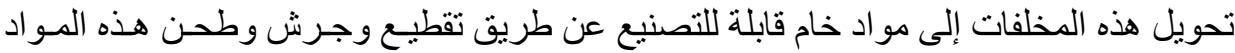

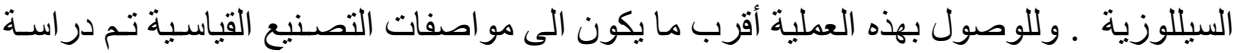

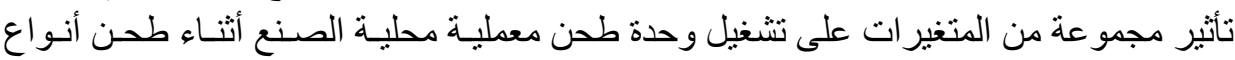

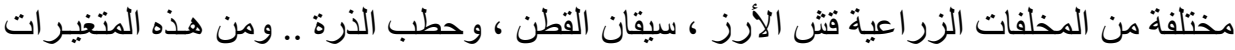

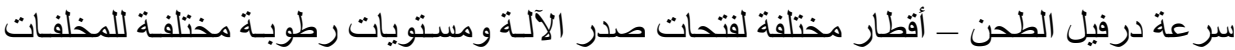

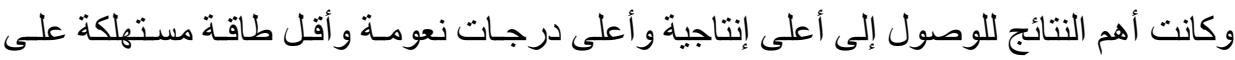

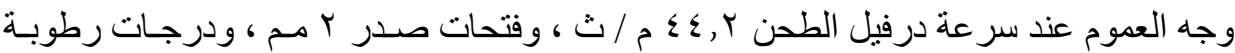

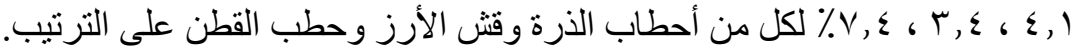

